\title{
Ketoconazole Blocks Adrenal Steroidogenesis by Inhibiting Cytochrome P450-dependent Enzymes
}

\author{
David S. Loose, Patricia B. Kan, Margaret A. Hirst, Robert A. Marcus, and \\ David Feldman, Stanford University School of Medicine, \\ Department of Medicine, Stanford, California 94305
}

\begin{abstract}
A B S T R A C T Ketoconazole has recently been shown to interfere with steroidogenesis in patients and rat in vitro systems. In this study we attempted to elucidate the site of inhibition in the adrenal gland. Although ketoconazole impaired adrenocorticotropic hormone stimulated cyclic (c)AMP production, dibutyryl cAMP addition did not bypass the steroidogenic blockade indicating that the critical ketoconazole-inhibited step was distal to cAMP. Addition of radiolabeled substrates to isolated adrenal cells and analysis of products by high performance liquid chromatography demonstrated a ketoconazole block between deoxycorticosterone (DOC) and corticosterone. This 11-hydroxylase step is carried out by a P450-dependent mitochondrial enzyme. No restriction of progesterone or pregnenolone conversion to DOC was detected, steps carried out by non-P450-dependent microsomal enzymes. Inhibition of cholesterol conversion to pregnenolone by mitochondrial fractions indicated a second block at the side chain cleavage step, another mitochondrial P450-dependent enzyme. Adrenal malate dehydrogenase, a non-P450-dependent mitochondrial enzyme was not inhibited while renal 24-hydroxylase, a P450-dependent mitochondrial enzyme in another organ, was blocked by ketoconazole. We conclude that ketoconazole may be a general inhibitor of mitochondrial P450 enzymes. This finding suggests that patients receiving ketoconazole be monitored for side effects relevant to P450 enzyme inhibition. Further, we raise the possibility that this drug action may be beneficially exploited in situations where inhibition of steroidogenesis is a therapeutic goal.
\end{abstract}

Address all correspondence to Dr. Feldman. Received for publication 1 January 1983.

\section{INTRODUCTION}

Ketoconazole has been an efficacious antimycotic agent because of its minimal toxicity and its effectiveness after oral administration against a wide range of fungal pathogens (1). However the appearance of gynecomastia in a few patients (2) was suggestive of a drug-hormone interaction. We and others recently showed that ketoconazole interfered with the production of adrenal (3) and gonadal steroids (4) both in patients and rat in vitro systems. These findings raised the possibility that ketoconazole, or a specifically designed analogue, could have additional utility as an inhibitor of steroidogenesis in the myriad clinical settings where reduction of steroid production would be useful, including Cushing's syndrome, hirsutism, and hormone-dependent cancers. We therefore pursued our studies of ketoconazole action to elucidate the step(s) in the steroidogenic pathway that were blocked by this antimycotic agent. The present paper demonstrates that ketoconazole inhibits adrenal mitochondrial P450-dependent enzymes. We detected inhibition of both the cholesterol side chain cleavage step as well as the 11-hydroxylation step. In addition, a kidney mitochondrial P450 enzyme, 25-hydroxy vitamin D-24-hydroxylase, was also blocked, suggesting that ketoconazole may have the general property of inhibiting P450-dependent enzymes. In the light of these findings additional side effects of ketoconazole relevant to P450 inhibition should be closely monitored. Moreover, we believe that studies to exploit this enzyme-blocking activity of ketoconazole in new clinical situations are now warranted.

\section{METHODS}

Adrenal preparations. Female Sprague-Dawley rats, 220-300 g, were decapitated and the adrenal glands re- 
moved. Isolated adrenal cells were prepared by collagenase digestion as previously described (3). DNA was measured by the diphenylamine method (5). Rats that were ether-stressed for $10 \mathrm{~min}$ to raise endogenous adrenocorticotropic hormone $(\mathrm{ACTH})^{1}$ were used to prepare adrenal mitochondria by the method described by Mason et al. (6).

Corticosterone and cyclic (c)AMP. Total cAMP (cells and medium combined) was extracted into $6 \%$ trichloroacetic acid, neutralized by the addition of $\mathrm{CaCO}_{3}$ (7), and measured by radioimmunoassay (Becton, Dickinson \& Co., Orangeburg, NY). Corticosterone was extracted from the medium with methylene chloride and measured by radioimmunoassay as previously described (3).

Steroidogenic studies. After $15 \mathrm{~min}$ of pretreatment of isolated cells or mitochondria with ketoconazole or vehicle (saline), radioactive substrates were added $(0.5-1.0 \mu \mathrm{Ci} / \mathrm{ml})$ to begin the assay. Incubations were carried out for 5-120 min at $37^{\circ} \mathrm{C}$ under $95 \% \quad \mathrm{O}_{2}: 5 \% \quad \mathrm{CO}_{2}$. The reactions were stopped by centrifugation and radiolabeled products in the medium were extracted in $10 \mathrm{vol}$ of chloroform $/ \mathrm{methanol}$, 2:1 (8). Following a wash with methanol/saline/chloroform 47:50:3 (Folch wash), the organic phase was taken to dryness under nitrogen. Samples were redissolved in $70 \%$ methanol and an aliquot was injected into a Varian model 5000 high performance liquid chromatograph (HPLC) equipped with a $30 \mathrm{~cm}$ reverse-phase column (Varian $\mathrm{MCH}-10$, Varian Associates, Inc., Palo Alto, CA). The mobile phase was methanol and water. $\left[{ }^{3} \mathrm{H}\right]$ Cholesterol $(47 \mathrm{Ci} / \mathrm{mmol})$, $\left[{ }^{3} \mathrm{H}\right]$ deoxycorticosterone $\left(\left[{ }^{3} \mathrm{H}\right] \mathrm{DOC}\right)(40 \mathrm{Ci} / \mathrm{mmol}),\left[{ }^{3} \mathrm{H}\right]-$ progesterone $(5 \mathrm{l} \mathrm{Ci} / \mathrm{mmol})$, and $\left[{ }^{14} \mathrm{C}\right]$ pregnenolone $(56 \mathrm{mCi} /$ $\mathrm{mmol}$ ) were all purchased from Amersham Corp. (Arlington Heights, IL). Radioinert steroids used for standards were purchased from Steraloids, Inc., (Wilton, NH).

24-Hydroxylase activity was assessed in a cultured pig kidney cell line (LLC-PK ${ }_{1}$ ) by measuring the conversion of 25-hydroxy $\left[{ }^{3} \mathrm{H}\right]$ vitamin $\mathrm{D}_{3}$ (Amersham Corp., $20 \mathrm{Ci} / \mathrm{mmol}$ ) to $24,25(\mathrm{OH})_{2} \mathrm{D}_{3}$ by an HPLC method (9). Adrenal mitochondrial malate dehydrogenase activity was measured by the method of Hoppel and Cooper (10).

\section{RESULTS AND DISCUSSION}

The first experiments were designed to evaluate the possibility that ketoconazole interfered with the initial steps of ACTH-stimulated corticosterone production. We reasoned that measurement of cAMP generation would allow detection of an inhibitor action at the level of the ACTH receptor, the regulatory protein or the adenylate cyclase system. As shown in Table I, ketoconazole did partially inhibit cAMP generation. However, the reduction in cAMP was disproportionately less than the ketoconazole effect to inhibit corticosterone production (3) and therefore did not seem adequate to explain the steroidogenic block. This is especially true in the light of the excess cAMP that is known to be generated in relation to that required for steroidogenesis (11).

\footnotetext{
${ }^{1}$ Abbreviations used in this paper: ACTH, adrenocorticotropic hormone; $b_{2}$ cAMP, dibutyryl cAMP; cAMP, cyclic AMP; DOC, deoxycorticosterone; HPLC, high performance liquid chromatograph $(y)$.
}

TABLE I

Effects of Ketoconazole on ACTH-stimulated cAMP

\begin{tabular}{cc}
\hline Condition & cAMP \\
\hline & $p m o l / \mu g$ DNA \\
Basal & $1.2 \pm 0.2$ \\
Ketoconazole & $2.6 \pm 0.8$ \\
ACTH & $6.2 \pm 1.8$ \\
ACTH + ketoconazole & $3.1 \pm 0.4$ \\
\hline
\end{tabular}

Total cAMP (cells plus medium) was measured by radioimmunoassay after $30 \mathrm{~min}$ of incubation in the presence of ACTH (5 $\mathrm{ng} / \mathrm{ml})$ and/or ketoconazole $(5 \mu \mathrm{g} / \mathrm{ml})$. Values shown are means $\pm \mathrm{SE}$ of five experiments.

To ascertain whether the cAMP inhibition played a role in the ketoconazole blockade of corticosterone production, we performed a dibutyryl cAMP $\left(\mathrm{bt}_{2} \mathrm{cAMP}\right)$ "bypass" experiment. As shown in Table II, ketoconazole inhibited corticosterone production despite $\mathrm{bt}_{2} \mathrm{cAMP}$ addition. The inability of $\mathrm{bt}_{2} \mathrm{cAMP}$ to bypass the ketoconazole blockade indicated that the impairment in steroidogenesis was distal to the cAMP production step.

We next sequentially evaluated the three major distal sterodogenic enzyme steps by making additions of the relevant radiolabeled substrates to isolated adrenal cells and analyzing the products by HPLC (Fig. 1). With $\left[{ }^{3} \mathrm{H}\right]$ DOC as substrate, ketoconazole inhibition of 11-hydroxylase activity was observed. Using $\left[{ }^{3} \mathrm{H}\right]-$ progesterone as substrate, conversion to DOC was demonstrated showing substantial 21-hydroxylase activity; accumulation of DOC confirmed the 11-hydroxylase block shown previously. Similary, with $\left[{ }^{14} \mathrm{C}\right]-$ pregnenolone as substrate, conversion to progesterone and DOC but not corticosterone was detected demonstrating the presence of $3-\beta$-hydroxysteroid dehy-

TABLE II

Effects of Ketoconazole on $\mathrm{Bt}_{2}$ cAMP-stimulated Corticosterone Production

\begin{tabular}{cc}
\hline Condition & Corticosterone \\
\hline & $n g / \mu g D N A$ \\
Basal & $50 \pm 14$ \\
Ketoconazole & $23 \pm 9$ \\
$\mathrm{Bt}_{2} \mathrm{cAMP}$ & $136 \pm 8$ \\
$\mathrm{Bt}_{2} \mathrm{cAMP}+$ ketoconazole & $26 \pm 11$ \\
\hline
\end{tabular}

Corticosterone production was measured by radioimmunoassay after $60 \mathrm{~min}$ of incubation in the presence of $\mathrm{bt}_{2} \mathrm{cAMP}(1.0 \mathrm{mM})$ and/or ketoconazole $(5 \mu \mathrm{g} / \mathrm{ml})$. Values shown are means $\pm S E$ of four experiments. 


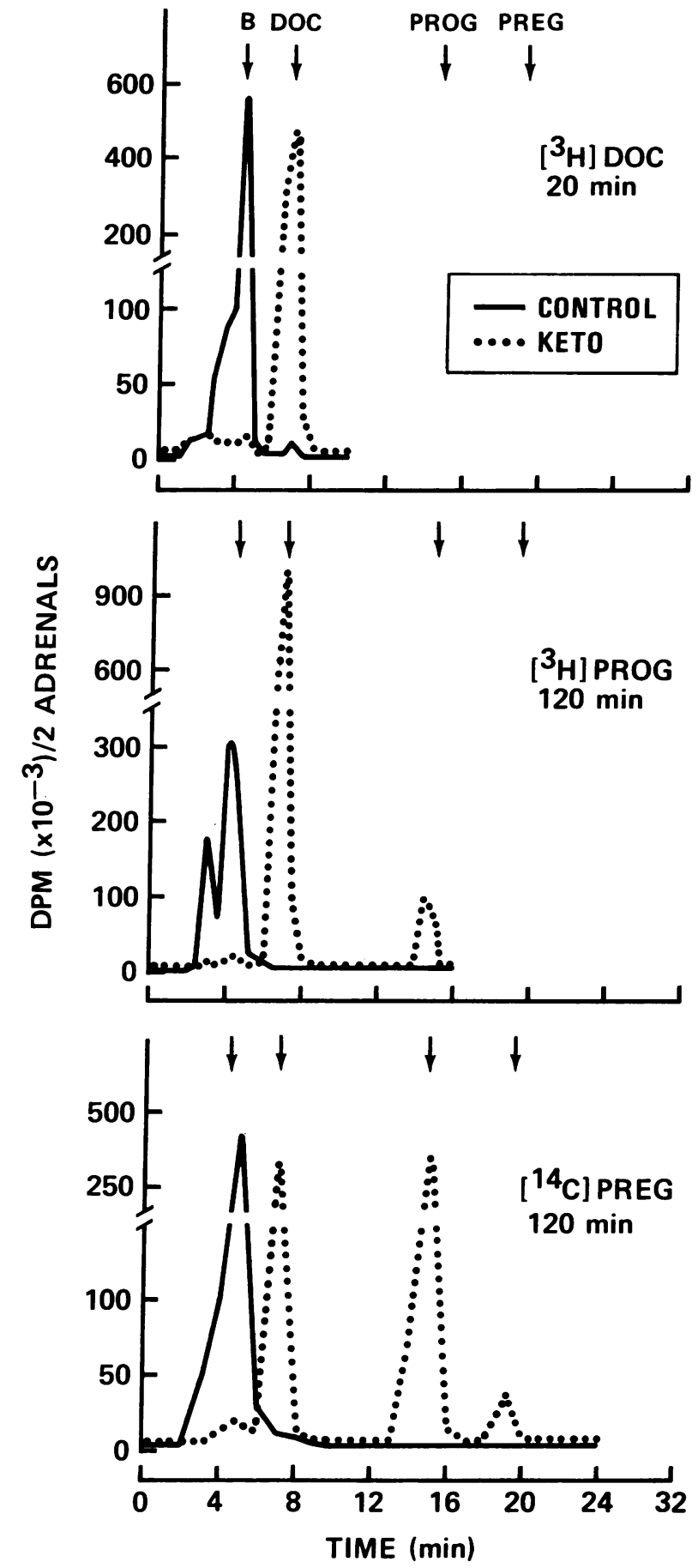

FigURE 1 Ketoconazole inhibition of 11-hydroxylase activity in intact adrenal cells. Isolated adrenal cells were pretreated with ketoconazole $(5 \mu \mathrm{g} / \mathrm{ml})$ or vehicle for $15 \mathrm{~min}$ and then the indicated radiolabeled substrates $(0.5 \mu \mathrm{Ci} / \mathrm{ml})$ were added. After 20 or $120 \mathrm{~min}$ of incubation, a Folch extract of the medium was chromatographed on a reversephase HPLC system in a methanol/water gradient at a flow rate of $2 \mathrm{ml} / \mathrm{min}$. The initial methanol concentration was drogenase, $\Delta^{5}-3$ oxosteroid isomerase, and 21-hydroxylase activities and again confirming blockade of 11hydroxylase activity. In experiments not shown, these effects of ketoconazole were demonstrated to be dose dependent between $0.1 \mu \mathrm{g} / \mathrm{ml}$ (minimal blockade) and $5 \mu \mathrm{g} / \mathrm{ml}$ (almost complete blockade).

To test the cholesterol side-chain cleavage reaction, $\left[{ }^{3} \mathrm{H}\right]$ cholesterol was added as substrate to an adrenal mitochondrial preparation. As shown in Fig. 2, cholesterol conversion to pregnenolone and more polar metabolites was well demonstrated in control samples but was significantly impaired in ketoconazole-treated samples. Similar experiments in mitochondrial preparations with $\left[{ }^{3} \mathrm{H}\right] \mathrm{DOC}$ as substrate demonstrated impairment of 11-hydroxylase activity but to a lesser degree than side-chain cleavage activity (data not shown).

Since the two blocked enzyme systems (side-chain cleavage and 11-hydroxylase) are both P450 dependent and mitochondrial in location, we thought it of interest to evaluate ketoconazole action on another mitochondrial P450-dependent enzyme in a different organ and on a non-P450-dependent adrenal mitochondrial enzyme. As can be seen in Fig. 3, ketoconazole caused a dose-dependent inhibition of renal 24hydroxylase, a P450-dependent enzyme, in LLC-PK cells. Of note is that the concentration of ketoconazole achieving $50 \%$ inhibition in the renal cells $(0.2 \mu \mathrm{g} / \mathrm{ml})$ is in close agreement with the concentration inhibiting $50 \%$ corticosterone production in adrenal cells, 0.3 $\mu \mathrm{g} / \mathrm{ml}$ (3). In data not shown, mitochondrial adrenal malate dehydrogenase activity, a non-P450-dependent enzyme, was not inhibited by concentrations of ketoconozole as high as $10 \mu \mathrm{g} / \mathrm{ml}$.

In summary, the data presented in this paper indicate that three mitochondrial P450-dependent enzymes in two different organs were inhibited by ketoconazole. No inhibition of non-P450-dependent enzymes was detected in three adrenal microsomal enzymes (3- $\beta$-hydroxysteroid dehydrogenase, $\Delta^{5}-3$ oxosteroid isomerase and 21-hydroxylase) nor one adrenal mitochondrial enzyme (malate dehydrogenase). We hypothesize that ketoconazole may be a general inhibitor of mitochondrial P450 enzymes. Since peak levels of ketoconazole in patients taking 200 or $400 \mathrm{mg}$ of drug per day are between 2 and $20 \mu \mathrm{g} / \mathrm{ml}(12)$, therapeutically achieved concentrations of drug are effective in inhibiting these enzymes and thus steroidogenesis. This finding is in accord with the previous in vivo studies $(3,4)$.

$70 \%$ increasing linearly to $100 \%$ between 15 and $17 \mathrm{~min}$, and continuing at $100 \%$ for the remaining elution period. The standards were run in the same system: B, corticosterone; DOC, deoxycorticosterone; Prog, progesterone; Preg, pregnenolone. 


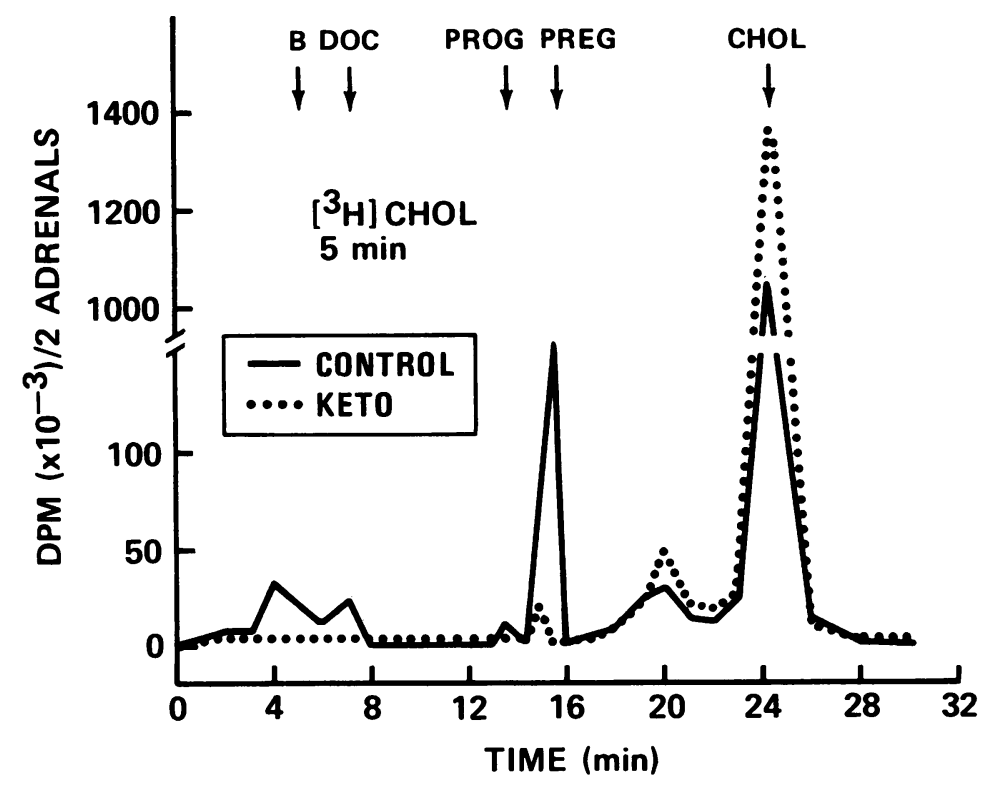

FIGURE 2 Ketoconazole inhibition of cholesterol side-chain cleavage activity in an adrenal mitochondrial preparation. A mitochondrial-enriched fraction from ether-stressed rats was pretreated with ketoconazole $(5 \mu \mathrm{g} / \mathrm{ml})$ or vehicle for $\left.15 \mathrm{~min} .{ }^{3} \mathrm{H}\right]$ Cholesterol $(1.0 \mu \mathrm{Ci} / \mathrm{ml})$ was added as substrate and incubated for $5 \mathrm{~min}$. Extracts were chromatographed on a reverse-phase column in a methanol/water system. The initial methanol concentration was $70 \%$, increasing linearly to $90 \%$ between 10 and $12.5 \mathrm{~min}$ and then to $100 \%$ between 12.5 and $15.5 \mathrm{~min}$. The standards, run in the same system, were: B, corticosterone; DOC, deoxycorticosterone; Prog, progesterone; Preg, pregnenolone; chol, cholesterol.

The postulated mechanism of action of ketoconazole, inhibition of fungal sterol synthesis, is presumed to occur at the 14-demethylation step in the conversion of lanosterol to ergosterol (13). Since this mixed func- tion oxidase may also be $\mathrm{P} 450$ dependent, it perhaps should not be surprising that similar mammalian enzymes are also affected. In the light of the current findings, what is most striking is the lack of toxicity

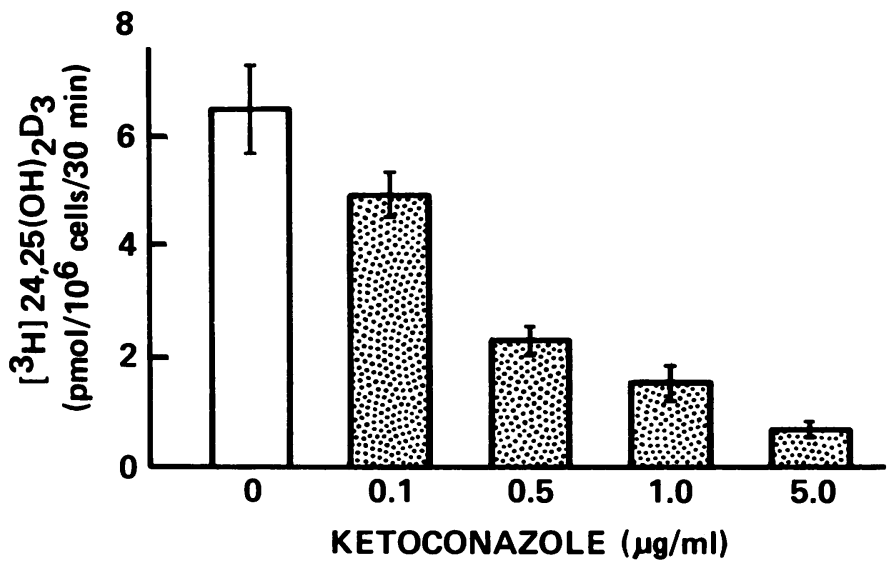

FIGURE 3 Dose-dependent ketoconazole inhibition of 24-hydroxylase activity in LLC-PK 1 cells. Cultured pig kidney cells were treated with $13 \mathrm{nM} 1,25(\mathrm{OH})_{2}$-vitamin $D_{3}$ for $6 \mathrm{~h}$, which induced a 26 -fold rise in 24-hydroxylase activity. Cells were treated with vehicle or ketoconazole for $30 \mathrm{~min}$ before measurement of enzyme activity. This was assessed by the rate of conversion of $\left[{ }^{3} \mathrm{H}\right] 25(\mathrm{OH}) \mathrm{D}_{3}$ substrate to $24,25(\mathrm{OH})_{2} \mathrm{D}_{3}$ product using HPLC with hexane/isopropanol 90:10 as the mobile phase. 
of ketoconazole noted thus far. This may relate to the pharmacokinetics of ketoconazole and the requirement for near peak concentrations of drug to inhibit the enzymes.

The information developed here regarding the actions of ketoconazole on mammalian P450-dependent enzymes indicates the need for continued careful monitoring of patients receiving this drug to detect specific side effects involving these very important enzyme systems. This is especially pertinent if the dose and/ or frequency of ketoconazole administration are increased. On the other hand, we believe that this action of ketoconazole, to impair steroid hormone synthesizing activity, may be usefully exploited in those clinical settings where inhibition of steroidogenesis would be a beneficial therapeutic goal.

\section{ACKNOWLEDGMENT}

This work was supported, in part by National Institutes of Health grant GM 28825 .

\section{REFERENCES}

1. Restrepo, A., D. S. Stevens, and J. P. Utz, editors. 1980 First International Symposium on ketoconazole. Rev. Infect. Dis. 2: 519-562.

2. De Felice, R., D. G. Johnson, and J. N. Galgiani. 1981. Gynecomastia with ketoconazole. Antimicrob. Agents Chemotherap. 19: 1073-1074.

3. Pont, A., P. L. Williams, D. S. Loose, D. Feldman, R. E. Reitz, C. Bochra, and D. S. Stevens. 1982. Ketoconazole blocks adrenal steroid synthesis. Ann. Intern. Med. 97: 370-372.
4. Pont, A., P. L. Williams, S. Azhar, R. E. Reitz, C. Bochra, E. R. Smith, and D. A. Stevens. 1982. Ketoconazole blocks testosterone synthesis. Arch. Intern. Med. 142: 2137-2140.

5. Burton, K. 1956. A study of the conditions and mechanism of the diphenylamine reaction for the colorimetric estimation of deoxyribonucleic acid. J. Biochem. 62: 315-323.

6. Mason, J. I., J. R. Arthur, and G. S. Boyd. 1978. Regulation of cholesterol metabolism in rat adrenal mitochondria. Mol. Cell Endocr. 10: 209-223.

7. Tihon, C., M. P. Goren, E. Spitz, and H. V. Rickenberg 1979. Convenient elimination of trichloroacetic acid prior to radioimmunoassay of cyclic nucleotides. Anal. Biochem. 80: 652-654.

8. Folch, J., M. Lees, and G. H. Sloane-Stanley. 1957. A simple method for the isolation and purification of total lipids from animal tissues. J. Biol.Chem. 226: 497-509.

9. Feldman, D., T. Chen, C. Cone, M. Hirst, S. Shani, A Benderli, and Z. Hochberg. 1982. Vitamin D resistant rickets with alopecia: cultured skin fibroblasts exhibit defective cytoplasmic receptors and unresponsiveness to 1,25(OH $)_{2} \mathrm{D}_{3}$. J. Clin. Endocrinol. Metab. 55: 10201022.

10. Hoppel, C., and C. Cooper. 1968. The action of digitonin on rat liver mitochondria. Biochem. J. 107: 367-375.

11. Dufau, M. L., and K. J. Catt. 1978. Gonadotropin receptors and regulation of steroidogenesis in the testis and ovary. Vitam. Horm. 36: 461-592.

12. Brass, C., J. N. Galgiani, T. F. Blaschke, R. Defelice, R. A. O'Reilly, and D. A. Stevens, 1982. Disposition of ketoconazole, an oral antifungal, in humans. Antimicrob. Agents Chemotherap. 21: 151-158.

13. Van Der Bossche, H., G. Willemsens, W. Cools, F. Cornelissen, W. F. Lauwers, and J. M. Van Cutsen. 1980. In vitro and in vivo effects of the antimycotic drug ketoconazole on sterol synthesis. Antimicrob. Agents Chemotherap. 17: 922-928. 